\title{
アナロジーを基盤にした認知的な葛藤の生起・促進とその解消 一中学生の「電流が十極から一極へ流れる」の意味理解一
}

\author{
内ノ良 真 吾*
}

\begin{abstract}
【要約】
中学校における電気単元を事例とし、アナロジーを基盤にして認知的な暮藤を生起・促進し、そ れを解消することで、科学的な理解が促進されること、およびそのアナロジ一の活用方法の有効性 を、質問紙調査㧍よびプロトコル分析によって探った。その結果、次のことが明らかとなった。

（1）生徒の学習前の科学的に適切とはいえない考えを代表するアナロジーと、それとは明確には異 なって、より科学的なモデルに近いアナロジーという、対照的な複数のアナロジーの導入は、認 知的な暮藤を生起・促進し、それを解消するという教授展開において有効であった。

(2) 背理法的な推論プロセスと関連付けて、生徒の考えを代表するアナロジーを評価すると同時に、 そのアナロジーによって、生徒の電流のモデルを評価するというプロセスを通じて、生徒の認知 的な葛藤を生起・促進する効果が認められたのであった。

（3）生徒の考えを代表するアナロジーの限界が明白になり、認知的な葛藤が高まった場面は、生徒 自身による新たなアナロジー生成の時機でもあった。このとき、科学的なモデルに近いアナロジー を導入することによって、先の認知的な暮藤が解消され、生徒の考えを変容・転換させることに つながり、生徒自身がその認知的な変容も実感しうるのであった。

(4) 構造化されたアナロジーによって、科学的な意味で未分化であった生徒の考えのうちに、関連 概念間の区別が意識化されるような、科学的な理解の促進効果があった。
\end{abstract}

\section{1.はじめに}

理科授業において、科学的な概念の形成を促進する上 で、子どもに認知的な葛藤を生じさせることが重要だと 考えられている。例えば、子ども達の素朴で日常的な概 念や考え方から科学的な概念や考え方への転換として理 科学習を捉えた場合、第一に、認知的な葛藤を引き起こ すことが概念変容の条件だと考えられてきた き、教授上の手立ての一つが、子どもの既存の考えとは 異なる現象（変則デー夕）を提示することであった2。 つまり、思考と現象のギャップや矛盾を提示することに 主眼が置かれていたのである゙!。

教授ストラテジーとしての認知的な葛藤研究をレ ビューしたリモン（2001）は、上述の変則データの提示 という方法は、葛藤を生じさせる唯一もしくは最善の方 法と考えられてきたものの、意四された葛藤がそもそも 子どもにとって意味のある葛藤になっていないという問

*静岡大学教育学部
題性を指摘している。その上で、グループでの議論の他 に、アナロジーやメタファーによって認知的な葛藤を生 起、促進することが有効でありうると示唆しているい”。 このことは、科学史を紐解くことでも推察されうるので ある。例えば、重い物体ほど先に落ちるというアリスト テレス的な運動論を論難したガリレオの『新科学対話』 には、背理法という演繹的な議論だけではなく、アナロ ジー的な議論も同時に認められ、ガリレオの運動論の展 開に双方重要であったと考えられている5”。ガリレオの 議論からの示唆として、アナロジーの導入次第では、単 純には経験的な問題には還元され得ない、思考の内にあ る矛盾を開示することが期待されうるのである。

一方、認知的な䓪藤に関わる教授場面では、もっぱら アナロジーは、それを解消する手段として活用されてき たのである ${ }^{6 !}$ 。例えば、デュパンとヨーサ（1989）は、 電気回路の電球の前後では、電流量が異なると思ってい る子どもに対して、電流計を使って、電流量が同じであ る、という自分の考えと矛盾する現象を提示していた。 
その後、列車のアナロジーの導入によって、消費される のが電流ではなくて、エネルギーであるという考えに導 いていた ${ }^{7}$ 。それに対して、認知的な葛藤を生起するも しくは促進する場面や機能に着目して、アナロジーの活 用方法、より具体的に言えば、アナロジーの内容選択、 導人時機、教授展開などは、検討されることがなかった。 そこで本研究では、中学校 2 年生の電気単元を事例に して、アナロジーを基盤にして認知的な葛藤を生起・促 進し、それを解消寸ることで、科学的な理解が促進され ること、およびそのアナロジーの活用方法の有效性を実 証的に明らかにしたい。

\section{2. 研究の方法}

\section{1）調查の対象と方法}

平成 22 年 7 月に静岡県内の国立大学教育学部附属 $\mathrm{A}$ 中 学校の 2 年生 2 クラス（77名）を対象にして、電気単元 の電気回路の導入段階の授業（1 時限分）を実施した。

いずれのクラスでも、筆者が授業を実施した。

生徒の電気回路を流れる電流についての考えは、生徒 用授業資料 (資料 1 ) の記述、授業中の生徒の発言 (VTR 録画、ICレコーダー録音）から探った。特に、本授業 で学習した内容については、生徒が実感を持って理解で きたところを把握することを礼らいとして、自由記述式 とした。

一方、本稿では、「認知的な葛藤」とは、生徒自身の 既存の知識や信念と本授業での学習内容や他の生徒の考 え、および自分自身の考えのうちにある別の側面との間 に生じうる葛藤として捉え、その状態とは、バーライン の指摘するような、疑い、当惑、矛盾、認知的不調和、 混乱、不適切さを感じる認知状態として把握した ${ }^{81}$ 。こ のような認知状態を生徒自身が捉えやすくするために、 各生徒のメ夕認知的能力の程度に左右されやすい分析的 な表現ではなく、葛藤が生じた状態やそれが進行する力 向を擬態語「モヤモヤ」、葛藤を生じていない状態やそ れが解消する方向を擬態語「スッキリ」として表現した。 授業では、「自分の頭のスッキリ度チェックシート」 ${ }^{9)}$ と 名付けた質問紙（資料2）を用い、生徒が授業の各段階で、 その程度を数值化して、自分の認知状態を捉えられるよ うにした（図 1）。

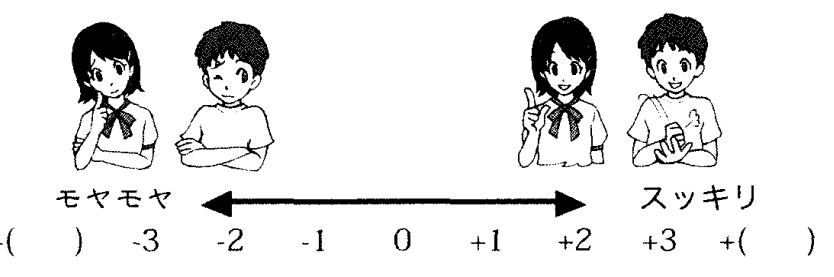

図1. 認知的状態の自己評価シート

認知的な葛藤の生起·促進と解消の分析にあたっては、 各授業段階（設定した段階については、後述の表 3 参照）
のモヤモヤ・スッキリ感を相互に比較した相対的な評価 と、授業を振り返っての全体的な評価の双方を利用した。 なお、前者の場合、生徒自身の既存の知識や信念が意識 化され、それと対立しうるような別の考えが提示されて 以降、授業の各段階でのスッキリ度の評洒が、前段階で の評価值よりもマイナス方向へと遷移した場合を、認知 的な葛藤が生起・促進されたものとし、そのような遷移 後の教授段階でプラス方向へと遷移した場合を、認知的 な葛藤が解消されたものと見なした。

\section{2）学習課題の設定とアナロジーの活用}

(1) 学習課題の設定とその観点

電気回路に流れる電流について、子ども達が多様な考 えをもっていることは、広く知られている。その中でも、 豆電球と乾電池を接続した単純な回路での電流の「単極 モデル」、「衝突モデル」、「減衰モデル」、「分配モデル」な どはよく知られたものである"1。このような電流のモデ ルが、子ども達の電流についての考え方のある種典型的 なものであるとした場合、そこには「電流が流れる」と は、単極・二極、一方向・二方向の如何に関わらず、「電 池から電流が放出される」(おそらく導線の中には、電気 もしくは電流のようなものは存在しない) という考え方 が基底にあることが示唆されうるのである。もしそうで あるとすれば、豆電球 2 個を直列に接続した場合、豆電 球が点灯するまでの時間には差異がある、と考える子ど もが多いと推測されるのである。そこで本授業では、子 ぞも達がもっている電流のモデルを意識化させ、それと の葛藤を生じさせるような授業展開に資するものとし て、表 1 のような学習課題を設定した。

\section{表1. 学習課題の設定}

$2 つ の$ 豆電球 $\mathrm{A} ・ \mathrm{~B}$ 、導線、電池をつなげた回路が あります。この回路では、豆電球 $\mathrm{A}$ と豆電球Bに明か りがつくまでの時間に違いがあるでしょうか。また、 そのとき、導線にはどのように電流が流れているで しょうか。自分の考えを文章や図で分かりやすく説明 して下さい。

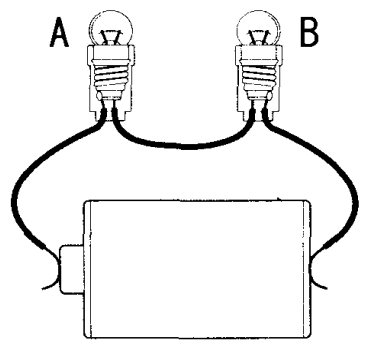

(2) アナロジーの導入とその意味内容

生徒の認知的な葛藤を生起・促進する場面、およびそ の認知的な暮藤を解消する場面で、次のようなアナロ ジーを導入した (表 2 )。本授業では、子ども達が直感 


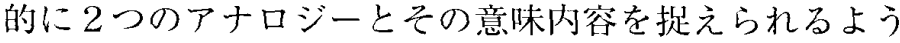
に、「電流が＋極から出発して、一極へと到着する」とい う考えを導くモデルを「かけっこモデル」、電流（もし くはその実体としての電子）が導線中に存在して扔り、 同時的に+極から一極へ向かって移動する」という考え を、「ところてんモデル」と名付けた。いずれのアナロジー であっても、本授業の主題である「電流が＋極から一極 へと流れる」ということの意味内容を捉えることに着目 したものであって、生徒の観点からいえば、「どうして豆 電球が点灯するのか」といった疑問を解消すること、科 学的な観点から言い換えれば、エネルギー变換を説明す ることをねらったものではない。

表2. 導入したアナロジーとその意味内容

\begin{tabular}{|c|c|c|}
\hline & かけっこモデル & ところてんモデル \\
\hline $\begin{array}{l}\text { 対応 } \\
\text { 関係 }\end{array}$ & $\begin{array}{l}\text { ランナーを電流、走路を } \\
\text { 導線、ハードルを主電球 } \\
\text { に対応付ける。 }\end{array}$ & $\begin{array}{l}\text { ところてんが電流で、大 } \\
\text { 突き器具を導線に対忍付 } \\
\text { ける。 }\end{array}$ \\
\hline $\begin{array}{l}\text { モデル } \\
\text { から導 } \\
\text { かれる } \\
\text { 考え }\end{array}$ & 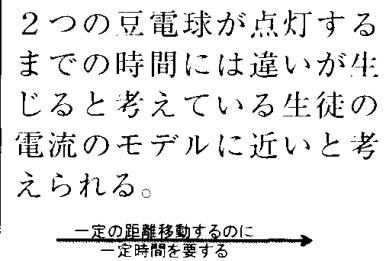 & 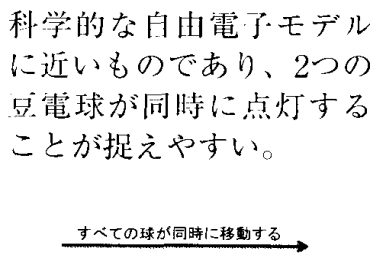 \\
\hline $\begin{array}{l}\text { 導入 } \\
\text { 場面 }\end{array}$ & 認知的な营藤の生起・促進 & 諗知的な苞藤の解消 \\
\hline
\end{tabular}

\section{3）授業の概要}

電気単元の電気回路の導入段階（静電気の学習を終え た後）で、アナロジーによって認知的な葛藤を生起・促 進させ、それを解消するという授業を実施した。主な学 習の内容と活動については、表 3 のとおりである。表3 の段階（2）から（4）までが、認知的な葛藤を生起・促 進する部分であり、その中心的な役割を担うものが、「か けっこモデル」というアナロジーであり、段階 (5) では、 その認知的な葛藤を解消する役割を担うものが、「ところ てんモデル」である。これらのアナロジーを導入する段 階では、単純に教師主導で上述のアナロジーを提示する のではなく、生徒自身にもアナロジーを生成する機会を 設定した。

\section{3. 生徒の学習課題の理解と認知状態の変容 \\ 1）生徒の学習課題の回答}

授業のはじまりの段階で記述式にて問うた、「2つの豆 電球 $\mathrm{A} ・ \mathrm{~B}$ 、導線、電池をつなげた回路では、豆電球 $\mathrm{A}$ と豆電球Bに明かりがつくまでの時間に違いがあるだろ うか」という問題に対して、生徒の回签は、表 4 のよう になった。
表3. 授業の流れと認知的な葛藤の生起・解消

\begin{tabular}{|c|c|}
\hline 学習の内容と活動 & 花滕 \\
\hline 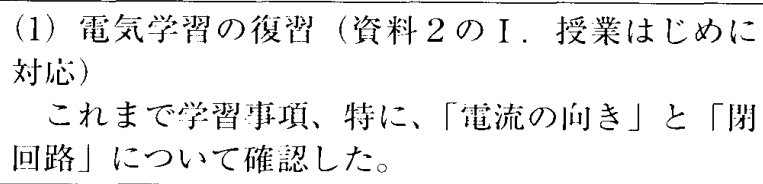 & \\
\hline 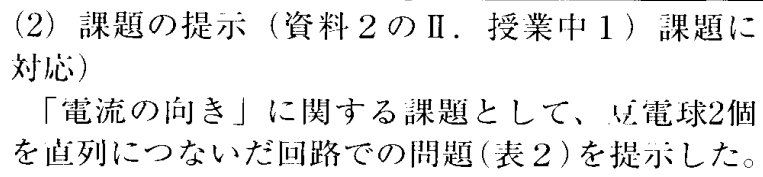 & \\
\hline 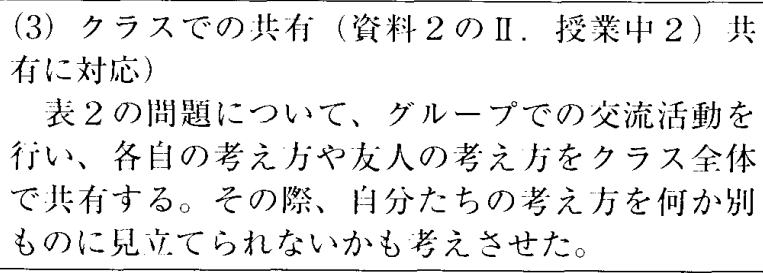 & 知 \\
\hline 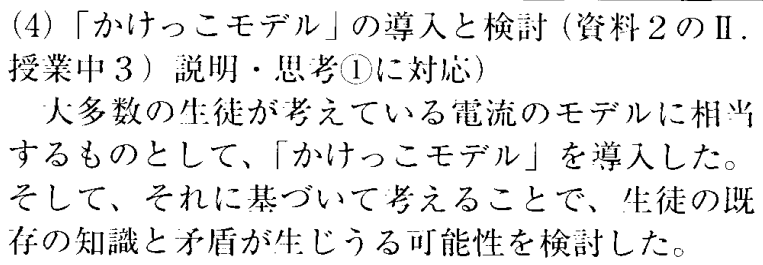 & \\
\hline 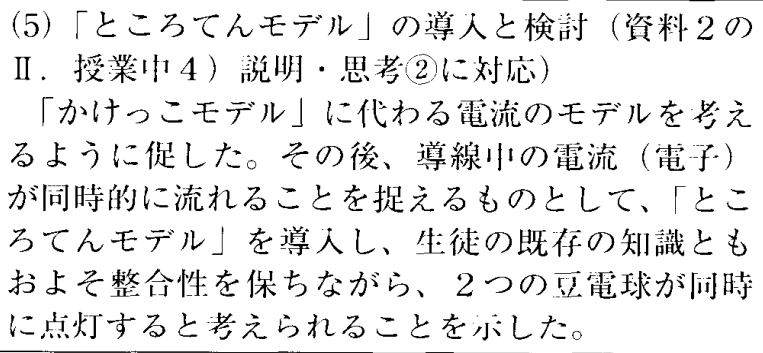 & 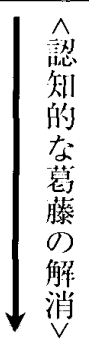 \\
\hline 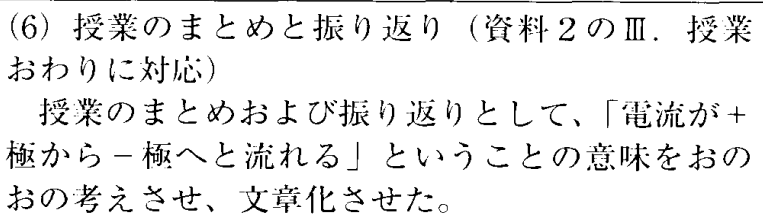 & \\
\hline
\end{tabular}

およそ全体の8割に相当する生徒の63名 $(81.8 \%)$ が、 $2 つ の$ 豆電球が点灯するまでの時間に違いがあると回答 した。そのうち、豆電球 $\mathrm{A} 、$ 豆電球Bの順序で点灯する と答えた生徒は、52名（67.5\%）で全体の 7 割近くを占

表4. 生徒の学習課題に対する回答

\begin{tabular}{|c|c|c|}
\hline 回答の類型 & 人数 & 割合 \\
\hline (1) 違いがある & 63 & 81.8 \\
\hline (1) $\mathrm{A} \rightarrow \mathrm{B} の$ 順序 & $(52)$ & $(67.5)$ \\
\hline (2) $\mathrm{B} \rightarrow \mathrm{A}$ の順序 & $(6)$ & $(7.8)$ \\
\hline (3) 順序は不明 & $(5)$ & $(6.5)$ \\
\hline (2) 違いがない & 10 & 13.0 \\
\hline (3) 両論併記 & 1 & 1.3 \\
\hline (4) 区別不能 & 3 & 3.9 \\
\hline 合 訫 & $77 人$ & $100.0 \%$ \\
\hline
\end{tabular}


内ノ倉 :アナロジーを基盤にした認知的な暮藤の生起・促進とその解消一中学生の「電流が十極からー極へ流れる」の意味理解一

めていた。その他に、豆電球B、豆電球 $\mathrm{A} の$ 順序で点灯 すると答えた生徒が 6 名 $(7.8 \%)$ おり、豆電球の点灯す る順序を明示していない生徒が5名(6.5\%)ほど見られた。 一方、2つの豆電球が点灯するまでの時間に違いがない、 と回答した生徒は、10名 (13.0\%) であった。その他にも、 点灯までの時間に違いがある場合とない場合の考え方の 双方を示したもの、両者のどちらの考えを支持している のか不明瞭なものが若干見受けられた（それぞれ、1名 $(13.0 \%) 、 3$ 名 $(3.9 \%)) 。$

どのように電流が流れるのかを捉えているのかとい う、生徒のもつ電流モデル（これについては、次章で报 う）と併せて考えなければならないが、電気回路の導入 段階である本授業のはじめの段階において、科学的な知 見（「2つの豆電球は同時に点灯する」) ${ }^{22} に 一$ 致する考 えをもっている生徒は、およそ1割であった。

\section{2）授業進行に伴う認知状態の変容の傾向}

一連の授業の中で 6 回に分けて、「自分の頭のスッキ リ度チェックシート」(資料 2 ) を活用して、生徒自身に 認知的な葛藤を含む認知状態を意識的に把握させた。各 回の認知状態とその相対的な位置付けが時間経過に伴っ て、どのように変化するのかに着目し、生徒の認知状態 の変容をグラフの形状として類型化したところ、一授業 時間中に極小值（「モヤモヤ」方向）を 2 度とる「W字形」 (図 2 、図中の各点を結ぶ太線は、筆者による。以下同様)、 極小值を 1 度とる「V字形」(図 3 )、授業開始時が極小值 であり、その後上昇もしくは横ばいの変化をたどる「右 肩上がり形」(図 4) の大きく3つに分類することがで きた。

表 5 のように、W字形の変化を見せた生徒は、30名 (39.0\%)、V字形の変化を見せた生徒は、38名 (49.4\%) であり、ほとんどの生徒が、アナロジーによる説明など の教授過程で、葛藤や不明瞭感などのモヤモヤ感が高ま るという状態を少なくとも 1 度は経験していたのであっ た。W字形とV字形の変化の違いは、課題を提示された

\section{表5. 授業進行に伴う認知状態の変容の傾向}

\begin{tabular}{|c|c|c|c|}
\hline 回答の類型 & $\mathrm{W}$ 字形 & $\mathrm{V}$ 字形 & 右肩上がり形 \\
\hline (1) 違いがある & 26 & 31 & 6 \\
\hline (1) $\mathrm{A} \rightarrow \mathrm{B}$ 順序 & $(25)$ & $(24)$ & $(3)$ \\
\hline (2) $\mathrm{B} \rightarrow \mathrm{A}$ の順序 & $(0)$ & $(5)$ & $(1)$ \\
\hline (3) 順序は不明 & $(1)$ & $(2)$ & $(2)$ \\
\hline (2) 違いがない & 3 & 6 & 1 \\
\hline (3) 雨論併記 & 0 & 1 & 0 \\
\hline (4) 区別不能 & 1 & 1 & 1 \\
\hline 合 計 & 30 人 & 38 人 & 9 人 \\
\hline
\end{tabular}

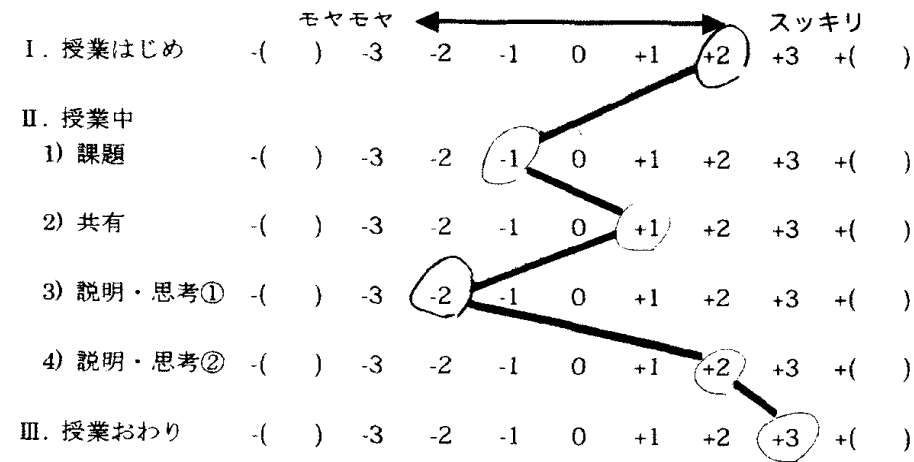

図2. 生徒の認知状態の変容例 (W字形)

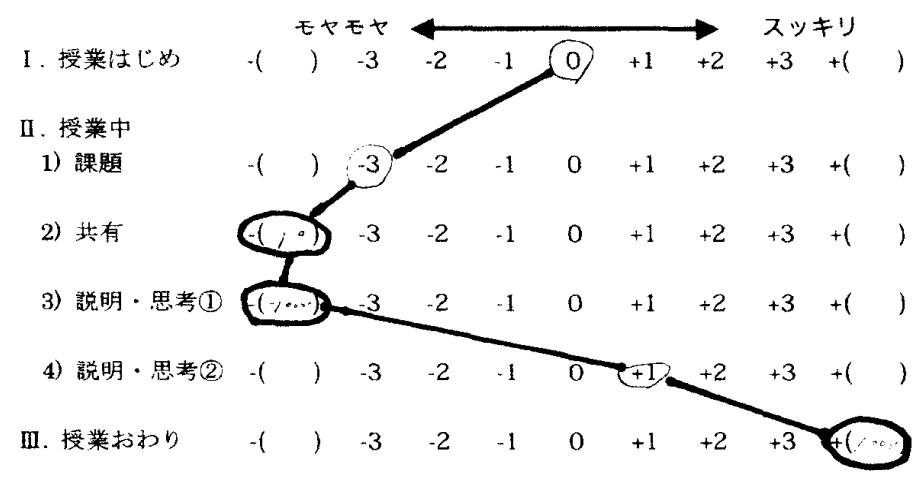

図3. 生徒の認知状態の変容例 ( $\mathrm{V}$ 字形)

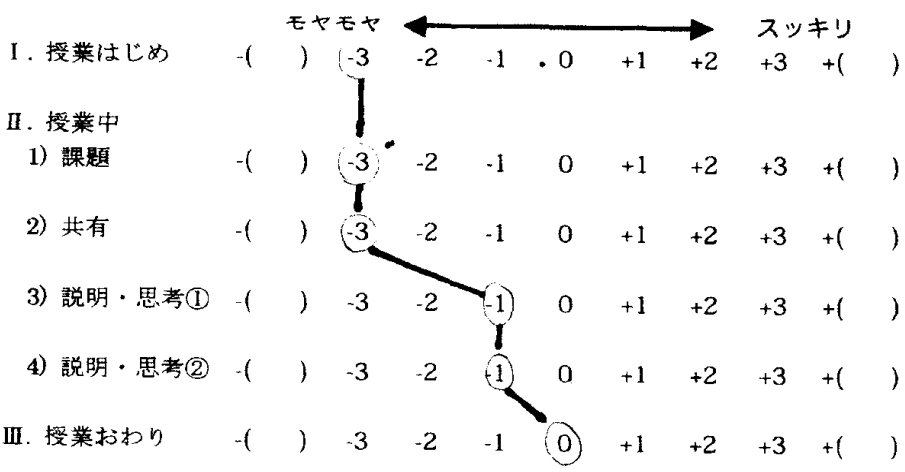

図4. 生徒の認知状態の变容例（右肩上がり形）

後のクラスやグループで共有した後の段階に見られてお り、自分と同じ意見や異なる意見を肯定的もしくは否定 的に捉えたかによって、いかに影響を受けたかが異なっ ていた。いずれの類型の生徒であっても、授業の後半に 向かって、スッキリ感が高まるという傾向が見られたの であった。

\section{3）授業後の「電流が流れること」の意味理解}

授業時間の最後の段階で、一連の教授内容等を振り 返って、改めて「電流が流れること」について分かった こともしくは考えたことを自由に記述するように求めた ところ、生徒が記述した内容の主たる観点は、電流の所 在、電流の速度、電流の流れ方、電流が流れ始める要因 の 4 つに分類できた。また、各生徒の自由記述には、複 数の観点が見られる場合もあり、観点ごとに計数したと ころ、表6のような結果が得られた。これらの観点に含 
表6. 授業後の電流の意味理解

\begin{tabular}{|c|c|c|}
\hline \multicolumn{1}{|c|}{ 回答の類型 } & 人数 & 割合 \\
\hline (1) 電流の所在 & & \\
\hline (1) 導線中の電流 (電子) の存在 & 44 & 57.1 \\
\hline (2) 電流の速度 & & \\
\hline $\begin{array}{c}\text { (1) 電流の移動速度とその効果（電 } \\
\text { 気エネルギー) の伝達速度の差異 }\end{array}$ & 23 & 29.9 \\
\hline (2) 電流の速度が遅い & 7 & 9.1 \\
\hline (3) 中央部と末端との速度の差異 & 3 & 3.9 \\
\hline (3) 電流の流れ方 & & \\
\hline (1) 電流の同時的移動（同時点灯) & 16 & 20.8 \\
\hline (4) 電流の流れ始める要因 & & \\
\hline (1) 電池＝ポンプ（流れをつくる) & 6 & 7.8 \\
\hline (2) 力学的な要因（玉突きなど) & 3 人 & $3.9 \%$ \\
\hline
\end{tabular}

まれなかった少数派の記述としては、電流を考えるとき にたとえやモデルが有効だと思った（10名、10.4\%）な どの思考スキルの重要性、あるいは本授業の満足感など に言及したものが見られた。

生徒の自由記述に見られた観点のうち、最も回答数が 多かったものは、電流の所在に関する記述であった。そ れは、本授業によって生徒の電流についての考えが大き く転換・変容した部分であった。授業開始段階で、導線 中に何かしら電流（電子）のようなものが存在している と考えていた生徒は、わずか5名だけであったが、授業 を通じて、記述の見られた少なくとも44名 (57.1\%) の 生徒が、電流の所在についての考えを転換・変容させる ことになった。

続いて、電流の速度に関する記述が、およそ $40 \% の$ 生 徒に認められた。これは、認知的な葛藤を解消するため の手立てとして、教師が導入した「ところてんモデル」 が、生徒の電流の出発・到着モデルの基底にあった「電 流（電気）の動きは速い」という考えと対立するものの、 電流（電子）それ自体の移動速度が遅くても、その効果 が速いこと（例えば、スイッチを入れると、即座に電灯 や電気機器が動き出すこと）を納得させうるのに十分で あったといえよう。ただ、一部の生徒（3名、3.9\%）は、 電流（電子）の移動速度と電気エネルギーの伝達速度と の違いを、導線の中央部と末端（スイッチ付近）での速 度の違いと䛊解していた。

\section{4. 既有知識としての「電流が十極から一極へ流れる」 とそのモデル}

\section{1）生徒の既有知識としての言語とモデルの関係性}

直列回路での $2 つ の$ 豆電球が点灯するまでの時間には 違いがあると考えた生徒と、違いがないと考えた生徒と の間には、現象の子測には違いがあるものの、「電流は+
極から一政へ流れる」という宣言的な知識もしくは文を 妥当だと見なしている点では、共通性が見られていたの である。しかしながら、その意味内容のレベルでは、科 学的な知見を共有していなかったのである。つまり、生 徒の言語表現と科学者共同体での言語表現との同一性 は、必ずしも、当該表現の意味内容の同一性を含意して いるのではない。また、言語表現に限らず、電流の流れ を示した図であっても、表現様式の同一性が認められた としても、その含意する内容は異なっている可能性があ る。このことは、科学理論の意味論的捉え力 $j^{131}$ を援用す れば、電流は＋極から一極へ流れる」という文の形式に とばの統語構造）に差異があるのではなく、むしろ、そ の文が当てはまる（意味論的な対応関係を持ちうる）電 流のモデルが異なるものとして解釈できる。そして、こ のモデル自体が、一種の理論という科学的な知識として 考えられるのである。ちなみに、構文論的捉え方に立て ば、上述のような文やその集合が科学的な知識（＝理論） ということになる。いずれにせよ、構文論的なレベルと 意味論的なレベルのいずれかに基準を設定するかによっ て、生徒の理解の程度やその意味内容にはギャップが存 在しうることを示唆しているのである。

以下では、生徒が「電流は＋極から一極へ流れる」と いう文を当てはめる、電流の主要な2つモデル（電流の 出発・到着モデルと一体的移動モデル）の意味内容を検 討することにしたい。

\section{2)「電流が十極からー極へ流れる」のモデルとその意味 内容}

(1) 電流の出発・到着モデル

抢よそ 8 割の生徒が、值列回路での 2 つ豆電球が点 灯するまでの時間には違いがあるのではないか、と考え ていたが、その基底には、「電流は＋極から一極へ流れる」 という文が当てはまるのとして、電流の出発・到着モデ ルがあった。すなわち、それは、乾電池の+極から電流 が出発して、まず豆電球 $\mathrm{A}$ 一到達し、続いて、豆電球 $\mathrm{B}$ へ到達し、最終的に一極へと到着する、という電流のモ デルである（図 5、図6。図中の「生徒A」とは、特定 の生徒を指すものであり、記号が異なる場合は、異なる 生徒を指している。以下、同様)。生徒によっては、乾 電池の内部を電流がさらに一極から+極へと移動すると も考えている。いずれにせよ、電流は、十極から「出発」 して、一極へと「到着」するものとして概念化されてい るのである。

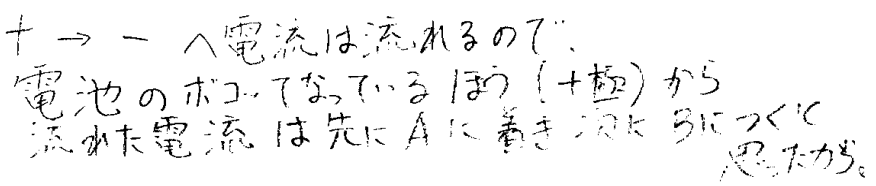

図5．生徒Aによる豆電球Aが先に点灯する理由 
内ノ含：アナロジーを基盤にした認知的な葛藤の生起・促進とその解消－中学生の「電流が+極から一極へ流れる」の意味理解一
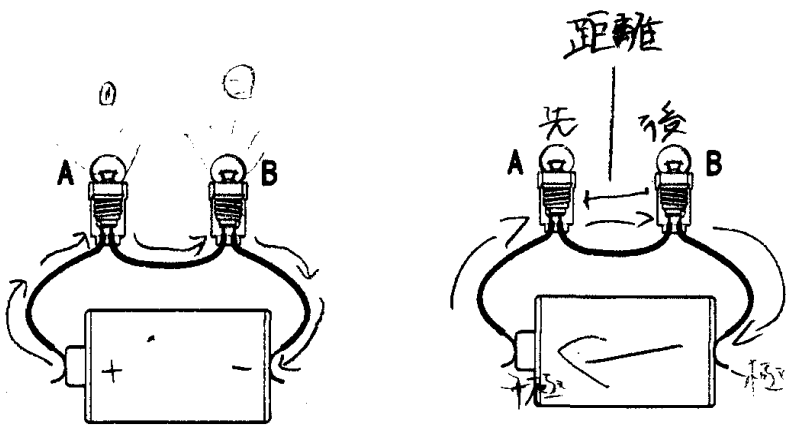

図6. 生徒B・Cによる電流の流れ方と点灯順序

したがって、電流がかなりの速度で移動するもので あったとしても、電流の出発・到着モデルに基づく限り においては、電流が放出される乾電池の+極に近い豆電 球Aの方が、わずかばかりの差であっても先に点灯する はずだ、という考えへといたるのであった。な挍、電流 の出発・到着モデルを共有している生徒の中には、豆電 球が点灯するのは、電流のループが完成したときであり、 同時に点灯すると考えている生徒も一部含まれていた。

豆電球が点灯するまでの時間に違いがあると考えた生 徒に、自分自身の電流のイメージを何かにたとえるよう に促したところ、1人の生徒Dから、「流しそうめん」と いうたとえが提案されたのであった。このたとえでは、 電気回路を流しそうめん器、電流をそうめん、電球を人 間に見立てて抢り、そうめんが最初に到達する方から豆 電球が点灯することを説明するものであった。このとき、 そうめんが食されてなくなっていくこととのアナロジー から、電流も豆電球で消費される、という考えも含意し ているのであった（表7の下線部（i ））。

\section{表7. 生徒Dの流しそうめんとのアナロジー}

T：違いがないという、あると考えた人は、イメージっ て、何にたとえられるかな。自分らの。扔、いいね、 ちょっとじやあ。D君か。D君だっけ、今のみんな に聞こえるように。はずがしがらないで。うん、い いよ。

D：(i 流しそうめんがこうやってあって。そこに2人 の人間が立っていて、それであの、たくさんがあっ と一気に流れ来て、たくさんのそばが、麺が流れて きて。流れてきて、最初の人の方が先にキャッチで きる。

T：うんうん、なるほど。流れてくるそうめんって、何 だろう。じゃあ、電気回路でいくと？

$\mathrm{D}$ : 電流で。

$\mathrm{T}$ : 電流で。

$\mathrm{D}: 2$ 人の人が電球で。

$\mathrm{T}$ ：電球だと。うん、回ってくる最初でいっぱいとっ ちゃったら、後の人はないよって？ああ、流しそう めんね。
一方、豆電球Bの方が先に点灯すると考えた生徒に は、「電流が+極からー極へと流れる」ということを、乾 電池の内部を+極から一極へと流れると捉えている生徒 と、電流の実体としての電子の存在とその移動の方向が 一極から+極であることを知っていた生徒を確認するこ とができた。いずれであっても、出発・到着モデルと同 等であった。

\section{(2) 電流の一体的移動モデル}

2つの豆電球が点灯するまでの時間には違いがない、 と考えていた生徒は、導線中には既に電流もしくは電子 が存在しており、スイッチが入ると同時に、これらが一 斉に移動するようなもの、言い換えるならば、電流の一 体的移動モデルと呼べるような考えに基づいて、同時に 点灯するととらえていた。例えば、生徒Eは、クラスの 大多数の生徒が考えている電流の到着・出発モデルと、 自分の考えが異なることを表明し（表 8 の下線部 $(\mathrm{i})$ )、 磁石と電池のアナロジー（表 8 の下線部（ii））、栓やダ ムなどでせき止めら扎た水と電流のアナロジー（表8の 下線部（iii））を引き合いに出した上で、電流が導管中 に既に存在しており、スイッチを入れると一斉に動き出 すために、2つの豆電球が同時に点灯するに違いない、 と主張したのであった。

\section{表8. 生徒Eの水流とのアナロジー}

$\mathrm{E} ：$ ，電流が流れるけど、僕が考えるのは、電池から 流れるだけではなくて、電池をつけることによって、 導線の中の、中にあるものが動く。要は、(ii) 電池は 磁石のようなもので、吸い付けて、反発して、こう やって (手で円を描きながら) サイクルになるじや ないかと思っていて。(iii)で、斜めの中になってい る水をせき止めて抏いたら、せき止めておいた水が 下のやつから全部がーって流れていくのではなく て、全部いっしょにがーって流れていく、一斉に流 れていくじゃないですか。なので、その導線の中も 一斉にがーって回るから、えーっと、 $\mathrm{A} の$ 部分も $\mathrm{B}$ の部分も同時に流れていくから。

( $\mathrm{E} ：$ 生徒 $\mathrm{E})$

この電流の一体的移動モデルであっても、前述の出発・ 到着モデルであっても、電流が+極からー極へと移動す るという電流の向きは、その意味内容に含まれているが、 導線中に電流（電子）の存在を含意しているかどうかと いう点で、決定的な差異があった。

\section{5. 生徒の認知状態とアナロジーの導入時機およびその 機能}

1）アナロジー導入以前の認知状態とその恋容

授業進行に伴う認知状態の変容について、W字形、V 字形のいずれの変化を見せた生徒も、もっともモヤモヤ

( $\mathrm{T} ：$ 教師、 $\mathrm{D} ：$ 生徒 $\mathrm{D})$ 
感が高まった状況とは、教授過程と対応付けていえば、 「かけっこモデル」を批判的に検討する場面であった。 これに加えて、W字形では、2つ目の極小值をとる場面 とは、学習課題（表2）を提示され、それに取り組んで いる場面であったが、それは、その直後のグループやク ラスで共有の場面での感じ取り方の差異を反映した結果 であった。

つまり、W字形の変化を示すことになる特徒は、課 題の回答そ扎自体には、必ずしも自信を持っていなかっ たようであるが、グループやクラスで考えを基有した結 果、圧倒的多数が自分と同意見であることを確認できた という安心感を得て、スッキリ度が一時的に高まる傾向 が見られた。それに対して、V字形の変化を見せた生徒 は、其有の場面で、生徒Bの発言に見られるように、自 分とは異なる考え（「豆電球が点灯するまでの時間には 違いがない」）が、たとえや専門的用語（「自由電子」） などを使って提示されたことによって、自分の考えの確 かさが摇らぎ、結果として、スッキリ度が下降し続ける ことになったと考えられる。

\section{2）アナロジーの評価と認知的な葛藤の生起・促進}

(1) 生徒自身の電流のモデルの意識化と共有

前述のように、大多数の生徒は、「電流が+極から極へ流れる」ということを、科学的には適切とは言えな い電流の出発・到着モデルに基づいて考えていた。しか しながら、昱電球が点灯するまでの時間の違いとは、あ くまでも観察できるかできないか、という経験的な問題 に過ぎない、という意識が見られる（図 7 ）。

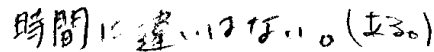

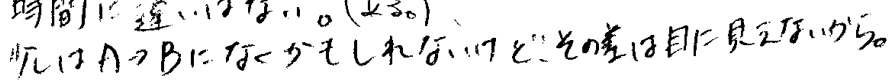

\section{図7. 生徒Fによる経験的な問題としての認識}

このモデルを生徒により身近なものであるかけっこに 見立て、そのモデルに内在する概念的な問題を意識化し やすくすることによって、概念的な葛藤を生起もしくは 促進することが意闵されていた。これには、授業を振り 返ったとき、自分の考えについての理解を深めるなどの メ夕諗知を促進する效果もあった。

\section{(2) アナロジーの評価とアナロジーによる評価}

2つの豆電球の点灯までの時間についての考えの如何 に関わらず、「かけっこモデル」、すなわち、電流の出発・ 到着モデルを仮に证しいとして、スイッチ開閉の3つの タイミング(電流がそれぞれ、ア、豆電球 $\mathrm{A}$ に到達する前、 イ、旦電球 $\mathrm{A}$ と $\mathrm{B} の$ 間、ウ。豆電球Bを通過した後）での $2 つ の$ 豆電球の点灯の可能性を判断させたところ、69名 (89.6\%) の生徒が、アの場合は両方とも点灯しない、イ の場合は豆電球 $\mathrm{A}$ み点灯する、ウの場合は豆電球A ·
Bの雨方が点灯する、という結果が予測されると考えた (図8)。
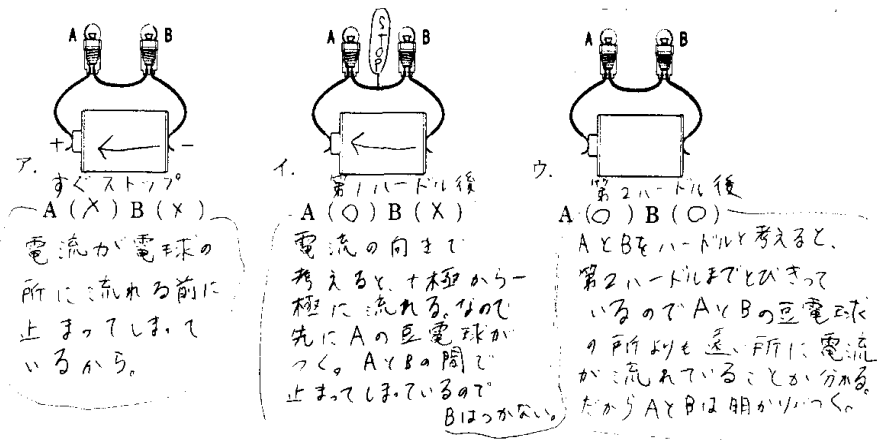

図8. 生徒Gによる「かけっこモデル」から導かれる

\section{豆電球の点灯}

しかしながら、この結果は、閉回路であれば（もちろ ん、電止などの条件が満たされている)、2つの豆電球 のいずれもが点灯する、という既存の知識とは矛盾し、 このままでは、スイッチの開閉のタイミングによって、 $2 つ の$ 豆電球が点灯するかどうかが異なる、という奇妙 な見解在受け人れなければならないことを示唆している のであった。つまり、この一連の過程は、かけっことの アナロジーをコンテクストにして、ある前提を正しいと 認めることによって、矛盾した結論が導かれるという背 理法的な推論プロセスであった。また、「かけっこモデ ル」を評価するという、モデリングの生成・評価・修正 サイクルの一段階であり、アナロジーの評価であると同 時に、アナロジーによる「電流の出発・到着モデル」の 評価でもあった。これまで、アナロジーに拈けるベース とターゲットとの対応関倸を評価することばかりに注意 が向けられる傾向にあっだ。今回のように、ターゲッ トが自然や科学的なモデルではない場合、ターゲットそ れ自体（ターゲットの内部構造）の評価も意識化されな ければならないのである。いずれにせよ、このとき、多 くの生徒は、認知的な葛藤の高まりを感じたのであった (図 9)。ただし、導かれた結論に疑問を感じた生徒に比 べて、矛盾している部分がどこであるのか（四10）、も しくは、何が要因で矛盾を引き起こしているのか、とい うところまでを的確に指摘できた生徒自体は、少なかっ た $(8$ 名、10.4\%)。

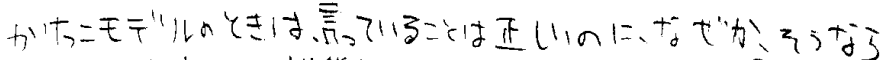

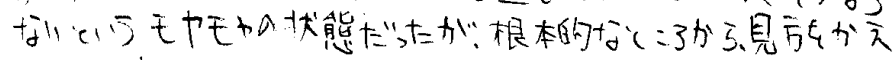
たら、スッキりできた。

図9. 生徒Hの認知的な葛藤状態の把握

$$
\begin{aligned}
& 2 \text { つも明がソがつかないのはおがいい。 } \\
& \text { つないであれば、2つ明ががつくはず。 }
\end{aligned}
$$

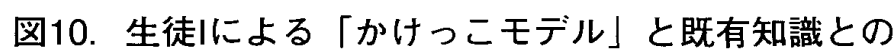
矛盾の指摘 
内ノ倉：アナロジーを基盤にした認知的な葛藤の生起・促進とその解消ー中学生の「電流が+極からー極へ流れる」の意味理解一

\section{3）アナロジーの生成・修正と認知的な葛藤の解消}

(1) 生徒によるアナロジー生成の促進

生徒の認知的な葛藤が高まったと判断された時点で、 スイッチの開閉のタイミングによって、2つの豆電球が 点灯するかどうかが異なるという奇妙な見解に到達する のは、そもそも「かけっこモデル」に基づいて考えるこ とが不適切であったのではないか、という問題提起を 行った。そして、どのようなものに見立てたほうがよい であろうか、と発問した。

\section{表9. 生徒によるアナロジーの生成}

$\mathrm{K}$ ：えーと、水にたとえて。導線を水として、豆電球を 水車として、電池をポンプとして考えれば、分かり やすい。

T：みんなどう？えー、そうだと水だと考えると、違い があるの? 違いがないの？

$\mathrm{K}$ ：あの、僕は電池の中に、電池の中から（電流が）出 て来ると思っていたんで、よくわかんないですけど、 $\mathrm{K}$ 君は、もともと導線の中に水が入っているといっ ていたんで、違いがないと。もともと（水がホース の中に）入っていて、ポンプがぷっと押したら、全 部が一気にがーって動くから、違いはないじゃない んすか。

T：ああ、違いがない。どうだろう、みんな分かった？ 今の説明。さっき、水は、一方からびゅーってでて、 こっちからここでホースに水が出て来るのではなく て、この中に水が全部詰まっているんじやないのっ ていう考え方だね。それだったら、違いがないんじや ないと。どうかなみんなは、他の人。L君だったかな。

$\mathrm{L}$ ：線路に、あの長い電車を怪力マンが

T：㧍っ、怪力マンが...

$\mathrm{L} ：$ どおっーって、押して

$\mathrm{T}:$ どおっーって…

L：全部の車雨がが一って押されていくみたいな。そう いう。電車がこっちからスタートするんじやなくて、 こっち(一つの輪になった車両) をボンっていう。

T：いっていることは分かるよ。みんなは分かったか な? 怪力マンがなんだろうって気にはなったけど、 ね(笑)。みんな分かった？他にいるかな？今、 水と怪力マン。拈っ、M君かな。もう一回言ってく れる?

$\mathrm{M}$ ：えっと、ただの管を

$\mathrm{T}$ ：カン？空き缶？

$\mathrm{M}$ ：缶じゃないですけど、管（くだ）。

$\mathrm{T}$ ：ああ、管（くだ）

$\mathrm{M}$ ：空気が入っている管を丸めて、輪っかみたいにして、 で、途中に何かブロアーつけて、で、輪つかにして つなぎ合わせることに、ブロアーみたいなのを、片 方から空気を吸い込んで、もう片方から空気を出す と。そそんなものをつなげると。で、空気の流れ、 つまり、中で回っている風、風みたいなものが電流 で...

（T：教師、 $\mathrm{K}$ ：生徒 $\mathrm{K} 、 \mathrm{~L}$ ：生徒 $\mathrm{L} 、 \mathrm{M}$ ：生徒 $\mathrm{M}$ )
表9に見られるように、あるクラスの生徒からは、電 流を水流、列車、空気などに見立てたアナロジー（下線 部）が提案されたのであった。別のクラスでも、水流と のアナロジーが示された。これらのアナロジーを提案し たのは、必ずしもはじめから電流の一体的移動モデルを 考えていた生徒ばかりではなかった（例えば、表 9 中の 生徒Kや生徒L)。このように、認知的な葛藤を解消する という場面では、生徒自身によるアナロジーの生成が促 進されるのであった（図11）。生徒から提案されたアナ ロジーは、ベースの種類こそは異なるものの、導線中に 電流（電子）が存在していること、それが一体的に移動 していることが、共通して含まれているのであった。
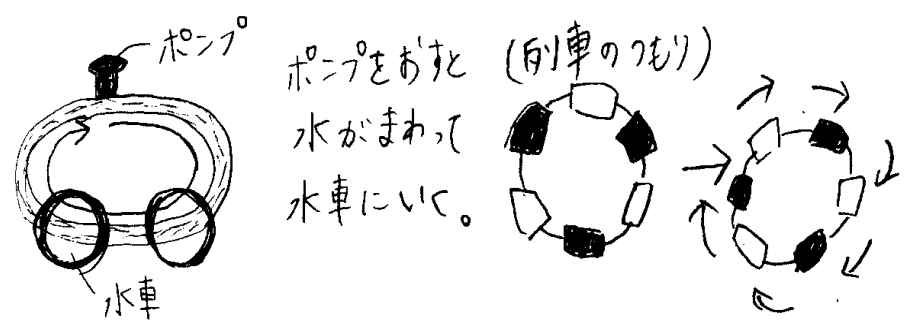

図11. 生徒I・Jによるアナロジーの生成

\section{(2) アナロジーによる概念変容とメ夕認知的な効果}

スッキリ度の変容過程からも見られるように、これら の生徒自身によるアナロジーの生成と教師によるアナロ ジーの導入の段階にいたって、一連の授業過程で高まっ ていた認知的な葛藤も解消されることになった。このこ とは、生徒 27 名 $(35.1 \%)$ は、自身の認知状態の変容を 振り返ったときの自由記述において、各種アナロジー、 特に、「こころてんモデル」が、モヤモヤを解消すること につながったことを明示していた。加えて、先行研究で も有効性が認められていたように涪、認知的な葛藤が高 まった場面でのアナロジーの導入は、概念変容を促進す る効果 ${ }^{16)}$ と同時に、それを意識化させる効果も認められ たのであった（図12）。

電流しいったらかけっこモデルのところばかり考えくいました

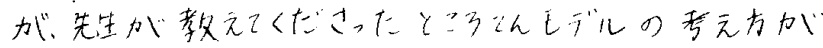

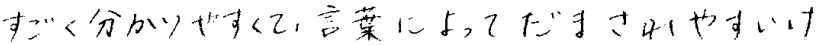

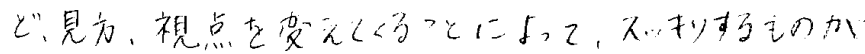
为方公分かり寻にた

\section{図12. 生徒Nによる認知的な変容の把握}

(3) アナロジーによる概念的な区別の促進

生徒が生成したアナロジーでは、電流が一体的に移動 することが捉えられていたが、電流の出発・到着モデル の基底にある「電流（電気）の動きは速い」という、科 学的には未分化の考えへのアプローチとしては十分では なかった。そこで、「ところてんモデル」を導入して、 
「電流（電子）の移動速度」と「電流（電気エネルギー） の伝達速度」との違い ${ }^{77}$ も、意識化させることをねらつ た。「ところてんモデル」については、ロ頭での説明に加 えて、ホースとビー玉を利用しての演示を行った。結果 として、生徒らは、電流の移動速度と電流の効果（電気 エネルギーの伝達速度）との概念的な区別ができるよう になった（図13）。

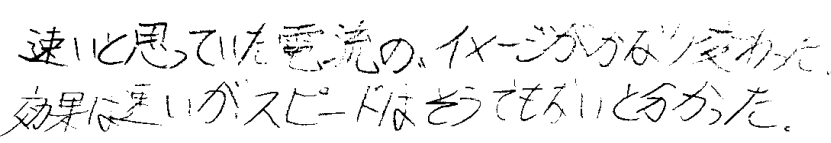

\section{図13. 生徒Oによる「電流の速さ」の概念的な区別}

このように、アナロジーでは、ベース（ところてんモ デル）とターゲット（電流）とが関係付けられるときに、 ベース内の構造（ホース内部のビー玉の移動の速さと末 端のビー玉が飛び出すまでの時間の関係）が、ターゲッ 卜内の構造（電流の移動速度と電流の伝達速度の関倸） へと対志付けられることになり、ターゲット内で曖昧で あった部分の構造化を促進する機能が、新たに認められ るのであった ${ }^{181}$ 。

\section{6. おわりに}

本稿では、中学校 2 年生の電気単元を事例にして、認 知的な葛藤という教授ストラテジー研究でも、アナロ ジー研究でも、これまで注目されることがなかった、認 知的な葛藤を生起・促進し、それを解消するというアナ ロジーの活用方法とその実践上の有効性を探ったとこ ろ、次のような知見が得られた。

第一に、生徒の科学的に適切とはいえない考えを代表 するアナロジーと、それとは明確には異なって、より科 学的なモデルに近いアナロジーという、対照的な複数の アナロジーの導入は、今回のような認知的な葛藤に着目 した教授展開において有効であった。複数のアナロジー の内容選択という観点から言えば、上述のような複数の アナロジーの選択は、意味内容の上で相補的もしくは问 等的な複数のアナロジーの導入を検討した先行研究 ${ }^{(9)}$ と は異なる試みであった。第二に、背理法的な推論プロセ スと関連付けて、生徒の考えを代表するアナロジーを評 価する（ベースとターゲットとの対応関係の評価）と同 時に、そのアナロジーによって、生徒の電流のモデル(「電 流の出発・到着モデル」）を評価する（ターゲットの内 部構造の評価）というプロセスを通じて、生徒の認知的 な暮藤を生起・促進する効果が認められたのであった。 第三に、生徒の考えを代表するアナロジーの限界が明白 になり、認知的な葛藤が高まった場面では、生徒自身に よる新たなアナロジーの生成が促進されることが分かっ た。第四に、認知的な葛藤が高まった場而では、科学的 なモデルに近いアナロジーを導入することによって、先 の認知的な葛藤が解消され、生徒の考えを変容・転換さ
せることにつながり、生徒自身がその認知的な変容も実 感しうるのであった。第四に、構造化されたアナロジー によって、科学的な意味で未分化であった生徒の考えの うちに、関連概念間の区別が意識化されるような、科学: 的な理解の促進効果が認められたのであった。

\section{謝辞}

静岡大学教育学部附属浜松中学校の山本仁副校長、龟 山壮志教諭には、本研究の授業実践の垁施に関して、貴 重な助言と多大な協力を賜った。また、高知工科大学の 八田章光教授には、電気回路の特性に関する専門的な知 識の教授を賜った。ここに記して、感謝の意を表したい。

\section{附記}

本研究の一部は、科学研究費（課題番号21730691）の 助成を受けて行われたものである。

\section{引用文献および註}

1) ストライク、ポスナー(著)、「概念転換として見た学: 岶と理解」、ウエスト、パインズ(編)、進藤公夫(監訳)、 『認知構造と概念転換』、266-270頁、1994、東洋館出版社。

2) クレメントは、概念変容 (conceptual change) とは、 学習者のメンタルモデルが進化 (evolve)していく過程 として捉えて扔り、その過程で有効な認知的なリソー スとして、先行知識と新しい観察や思考実験(thought experiment）を挙げている。その際、アナロジーは、 前者のカテゴリーに含まれるものとして、矛盾を引き 起こす事象もしくは発問 (Discrepant Event/Questioning) とは、区別している（pp.428-432）。Clement, J., “The Role of Explanatory Models in Teaching for Conceptual Change", in Vosniadou(ed.), International Handbook of Research on Conceptual Change. pp.417-452, 2008. Routledge.

3) ハッシュウェーは、認知的な葛藤（対立·衝突）を、 生徒のプレコンセプションと現実世界との対立、プレ コンセプションと科学的なコンセプションとの対立の 二つに分類し、一般的には、前者のみが注目される倾 向にあることを指摘している (p.240)。Hashweh, M. Z.. "Toward an Explanation of Conceptual Change". European Journal of Science Education, 8(3), pp.229249, 1986.

4) Limon, M., "On the Cognitive Conflict as Instructional Strategy for Conceptual Change: a Critical Appraisal", Learning and Instruction, 11, pp.373-374, 2001.

5 ）金子務、思考実験とはなにか一その役割と構造を探 る-』、208-230頁、1986、講談社。 
6）概念変容を促進する教授ストラテジーという点から 見れば、アナロジーとは、分かりやすく、納得しやす い新しい考えを導入する手段であるが、アナロジーに よる教授方法という点から見れば、認知的な葛藤を生 じさせた場面とは、アナロジーを効果的に導入しうる タイミングとしても捉えられる。内ノ倉真吾、「アナロ ジーによる理科教授法の開発とその展開一構成主義的 学習論の興隆以降に着目してー」、『理科教育学研究』、 50 (3)、27-41頁、2010。

7 ) Dupin, J.J., Johsua, S., “Analogies and “Modeling Analogies" in Teaching : Some Examples in Basic Electricity”, Science Education, 73(2), pp.211-216, 1989.

8 ） D.E. バーライン(著)、橋本七重、小杉洋子(訳)、『思 考の構造と方向』、296-300頁、1970、明治脳書。

9）この質問紙は、「運勢ライン法」の活用を参考にし、 生徒自身の認知状態を把握するメ夕認知的な道具とし て開発したものである。「運勢ライン法」については、 以下を参照されたい。ホワイト、ガンストン(著)、中 山迅、稲垣成哲（監訳）、『どもの学びを探るー知の 多様な表現を基底にした教室をめざしてー』、137-154 頁、1995、東洋館出版社。

11) Shipstone, D, "Electricity in Simple Circuits", in Driver et al.(eds.), Children's Ideas in Science, pp.35-40, 1985 , Open University Press (邦訳書、内田正男 (監訳)、『子 ども達の自然理解と理科授業』、52-57頁、1993、東洋 館出版社)。このモデルが日本の子どもにも適用でき るかどうかについては、安藤裕明、森藤義孝、中山迅、 「単純電気回路に関する小・中学生の考え方の再検討 一事象面接法を通して一」、『科学教育研究』、21(2)、

115-125頁、1997で詳しい検討がなされている。

12）本授業では、中学校理科カリキュラムの範囲を考虑 して、「2つの豆電球は同時に点灯する」を適切な理 解として位置付けた。もちろん、電磁波の伝播速度や 伝送経路という観点を考慮すれば、上記とは異なる見 解になりうる。

13）現代科学論では、科学理論の捉える現代的な立場と して、科学理論の構文論的捉え方と意味論的な捉え方 と呼ばれる、2つの立場がある。この 2 つの立場につ いては、以下に詳しい。戸田山和久、『科学哲学の冒険 ーサイエンスの目的と方法をさぐるー』、213-238頁、

2005、日本放送出版協会。森田邦久、『科学とはなにか - 科学的説明の分析から探る科学の本質 -』、151-156 頁、2008、昆洋書房。

14）例えば、グリンのTWAモデルというアナロジー教 授法では、(1)学習するターゲットの尊入、(2)ベースの 想起、(3)ベースの特徵の特定、(4)ベースとターゲット の類似する特徴の写像、(5)ターゲットについての結論 の導出、(6)アナロジーが破綻するところの特定、とい
う6つの手続きが提唱されている。Glynn, S. M. , "Explaining Science Concepts: A Teaching-WithAnalogies Model”, Glynn et al.(eds.), The Psychology of Learning Science, pp.219-240, 1991 , Lawrence Erlbaum Associates (邦訳 ; 稲垣成哲、「科学概念の説 明:アナロジーによる教授モデル」、武村重和（監訳）、 『理科学習の心理学』、240-265頁、1993、東洋館出版).

15）例えば、Treagust, D. F., Harrison, A. G., Vnville, G. J., Dagher, Z.R., "Using an Analogical Teaching Approach to Engender Conceptual Change", International Journal of Science Education, 18(2), pp.213-229, 1996.

16）デーガーは、知識内容レベルでの概念変容の程度や 範用については、多様な見解があり、アナロジー導入 による学習效果を同一に評洒しにくいという問題点を 指摘している。Dagher, Z. R, “Does the Use of Analogies Contribute to Conceptual Change?", Science Education, 78(6), pp.601-614, 1994. 一方、デュイットとトリガー ストは、今日的な見解として、知識内容レベルに留ま らず、情意的な側面やメ夕概念的な気付きなども射程 にして、概念変容を捉えることの重要性を指摘してい る。Duit, R., Treagust, D. F., "Conceptual Change: a Powerful Framework for Improving Science Teaching and Learning", International Journal of Science Education, 25(6), pp.671-688, 2003. 本稿では、デュイッ トらの指摘するように、教授前の生徒の考え力から、 学ばれる科学概念への学習経路」(673頁) という一般 的な意味で「概念変容」を捉えることにしたい。

17）「ところてんモデル」やそれに類似したモデルは、 粒子の速さとエネルギーの伝達速度との違いを教える ための手立ての一つとして構想されることはあった。 例えば、嶋田治、林良重 (編著)、『小学校・中学校 䛊 りすい理科 100 題 <物化編 $>』 、 92-93$ 頁、1972、東 洋館出版社。ただし、アナロジーと認知的な葛藤の生 起・解消とを関連付けるなどの教授展開の構想は、管 見の限りでは見受けられない。

18）理科学習におけるアナロジー研究をレビューした デュイットは、アナロジーの利点として、概念変容の 促進、抽象 (概念) の理解、抽象の視覚化、動機付け の四点を挙げている(p.666)。Duit, R., “On the Role of Analogies and Metaphors in Learning Science”. Science Education, 75(6), pp. 649-672, 1991.

19) Chiu, M.H., Lin, J.W. , “ Promoting Fourth Graders' Conceptual Change of Their Understanding of Electric Current via Multiple Analogies", Journal of Research in Science Teaching, 42(2), pp.429-464, 2005.

(2010年 9 月 9 日受付，2010年11月29日受理) 


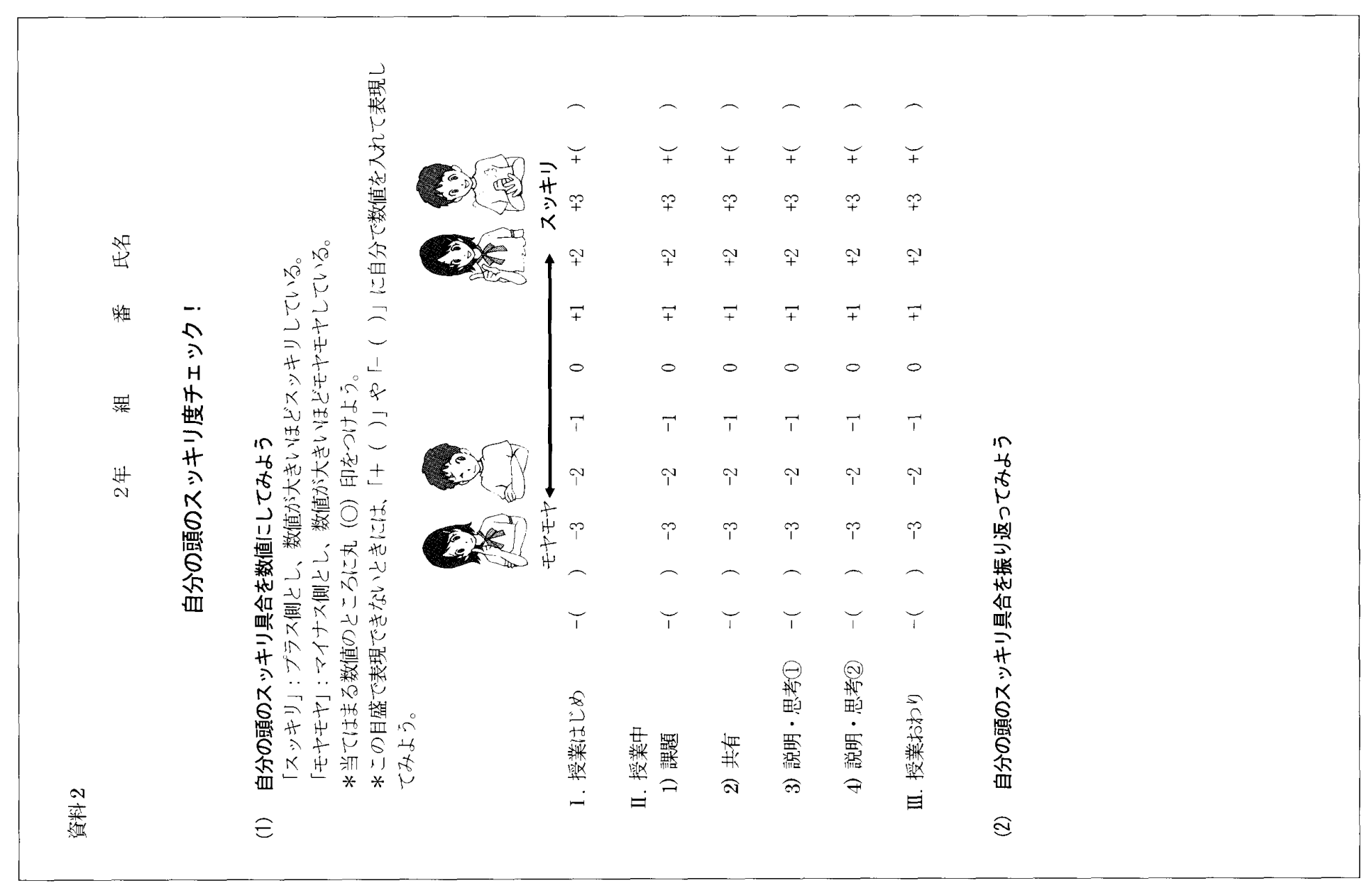

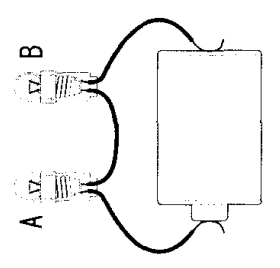

iो

tion

$s$ 掉 $\vec{r}$

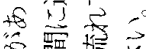

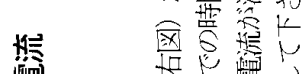

墭

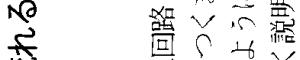

过管 5 t

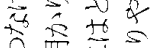

利贾器

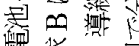

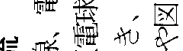

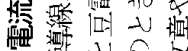

م.

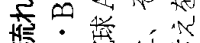

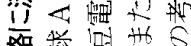

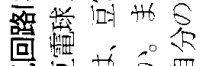

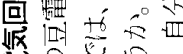

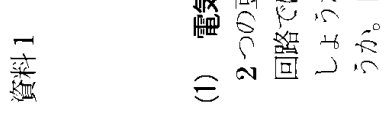
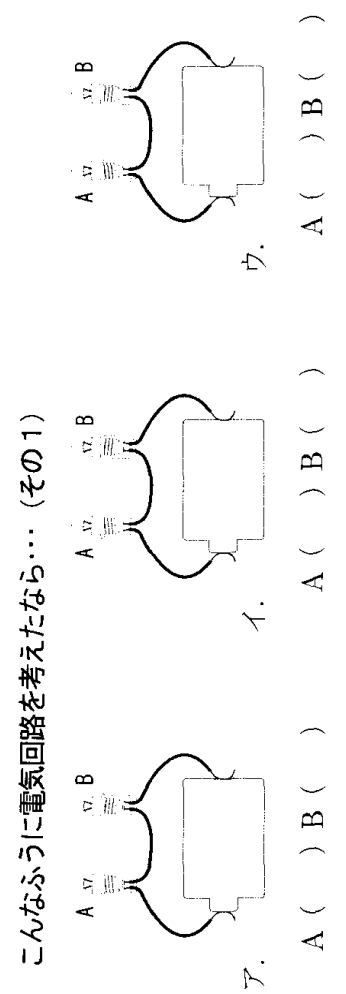

ล

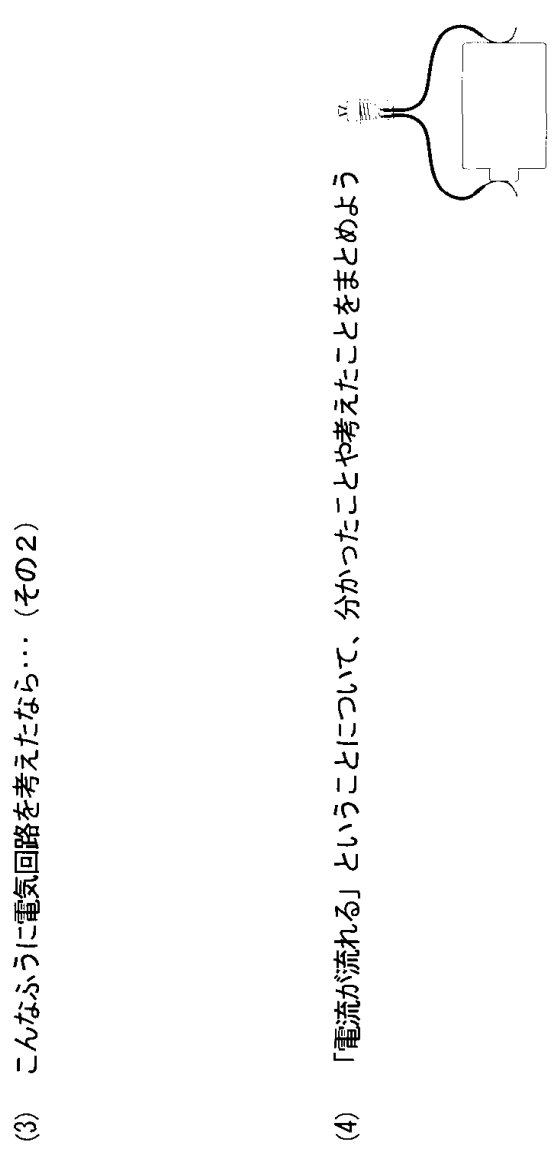




\title{
SUMMARY
}

\section{The Evoking and Resolving of Cognitive Conflict by Using Analogies in Science Learning: Secondary Students' Understanding of the "Direction of Electric Current"}

\author{
Faculty of Education, Shizuoka University \\ Shingo UCHINOKURA
}

This paper presents a process of evoking and resolving cognitive conflict with the help of analogies to teach the "direction of electric current" in secondary science classes. This process was examined with questionnaire and protocol analysis. Consequently, following points were revealed.

(1) Two kinds of analogies played an important role in this process. The first was represented as the students' model of electric current, and it implied that electric current begins at one pole and arrives at the other. In contrast, the second resembled a scientific model, and it implied that electric current/ free-electrons in every place begins to flow/move at the same time .

(2) After the first analogy was evaluated by a reduction of the absurd, the students became aware of the difficulties of their model and this evoked a cognitive conflict.

(3) This(the above mentioned (2)) was an opportunity to encourage the students to modify their analogies/models or to generate alternatives. The introduction of an alternative analogy, which was intelligible and plausible for the students to understand the direction of electric current, resolved the students' cognitive conflict, and they were comfortable with this change in cognitive status.

(4) This structured analogy was employed with conceptual differentiation in relevant scientific concepts that involve the flow rate of electric current (electrons) and the time required for electric energy transmission in series circuits. 